\title{
Social Changes of Traditional Rules in Facing Contemporary Developments: A Sociological Study of Intercaste Marriagein Balinese Society
}

\author{
Ida Ayu Sadnyini* and A.A.A. Ngurah Tini Rusmini Gorda \\ Universitas Pendidikan Nasional (UNDIKNAS), Jl. Bedugul, No.39, Sidakarya, Denpasar, Denpasar, Bali \\ 80224, Indonesia
}

\begin{abstract}
Nowadays, it is important to examine the impetus for changes of traditional rules in facing contemporary developments and in this regard, this study took a private subject of rules on inter-caste marriage in the Balinese Hindu community. In this context, this study aims to investigate how the inter-caste marriage system is run as an effort to bridge traditional values and modern values based on legal equality and citizenship by taking Balinese society. This research is empirical research with a historical approach with the object of the research is inter-caste marriages. The results showed that the development of inter-caste marriage rules in the monarchy period was derived from Hindu law. The rules on inter-caste marriage during the colonial period can be found in the Peswara and after the independence, the inter-caste marriage is regulated in the Decree of House of Representative of Bali Province, Bhisama Sabha Pandita, and the Decree of MDP Bali. The Hindu community still maintains the sanctions against inter-caste marriage because of their adherence to the customary law of the traditional village.
\end{abstract}

Keywords: Development, Changes, Traditional Rules, Private Subject, Marriage, Inter-Caste.

\section{INTRODUCTION}

Based on instigation in Hindu Law namely Manawa Dharmacastra, a man should marry a woman who has the same caste as him. In Customary Law, such a marriage system is called a caste endogamy marriage, or equal marriage, which is known as "pepadan" in Bali. The caste-basis marriage was also widely known in Hindu societies, such as in India and Nepal (Dhar, 2013; Saroja, 1999). According to Wiranata, the marriage system based on the necessity and the prohibition of looking for prospective wives for every male according to the view of various nations (ethnology) can be classified into three categories, namely the exogamy system, the endogamy system, and the eleutheromania system (Wiranata, 2005). However, this system has boundaries such as the prohibition of a marriage between a man and women based on customary law which is called parallel cousin (children of two sisters or children of two brothers) in the Balinese Hindu community. The cross-cousin marriage is also prohibited. The daughter of the sister should not marry the son of the brother. The prohibition of marriage is due to blood relations in the Balinese Hindu community. The prohibition for a woman to marry a man who has a lower caste in the Balinese Hindu community is called "nyerod" (Syahuri, 2013).

Legal political statements regarding parallel cousin and cross-cousin married were articulated through the

*Address correspondence to this author at the Universitas Pendidikan Nasional (UNDIKNAS), Jl. Bedugul, No.39, Sidakarya, Denpasar, Denpasar, Bali 80224, Indonesia; E-mail: iasadnyini.undiknas@gmail.com
Decree of the National Legal Planning and Development Agency (BPPHN) dated 28 May 1962 which abolished the prohibition of such marriage to implement the parental system in Indonesia (Syahuri, 2013). The democracy value in Pancasila also implies that the parental system should be disseminated, namely by removing the social levels or social stratification based on caste. The goal is to eliminate caste differences between husband and wife, as happened in the Balinese Hindu community.

Balinese Hindu community still maintains the rules on inter-caste marriage which regulated in Hindu Law, namely the Manawa Dharmacastra Book which distinguishes between the marriage of anuloma and pratiloma. Anuloma is a marriage between a man with a higher caste with a woman with a lower caste, which is known as a marriage that enhances social status. Pratiloma is a marriage between a higher caste woman with a man with a lower caste, which known as a marriage that degrades social status. In addition to the Manawa Dharmacastra, other books regulate intercaste marriage in Bali.

In the social context, the Balinese Hindu community is stratified into four castes known as catur wangsa, namely the system of the nation which consists of: brahmana, ksatrya, wesya, and sudra. Wangsa according to Djoyodiguno (1964) is interpreted as a descendant. During the era of Dutch Colonisation, caste, whatever the term used: Wangsa or Warna, gave certain legal implications in the marriage law, especially inter-caste marriage. Balinese Hindu 
community adheres endogamy marriage system. If a family member marries someone who comes from a different caste (exogamy), the marriage is considered degrading social status of the extended family. A woman from the Brahmana caste who marries a man with a lower caste is known as asupundung. Asupundung means that the Brahmana woman is described as a woman who carries a dog. The man who marries the woman is considered as a dog. On the other hand, if a woman from the Ksatrya caste marries a man with a lower caste, it is called alangkahi karanghulu. Kembar Kerepun described alangkahi karanghulu as a man with low caste who step over the head of the king (Kerepun, 2004), while Jiwa Atmaja described alangkahi karang hulu as an action which cross the sacred area (karang hulu) (Atmaja, 2008).

The shift in warna system toward wangsa system known as the caste system since the Dutch Colonisation in 1910. At that time, the King of Netherlands enacted Peswara (decree) which stipulates the types of customary violation and its sanctions. Violations against inter-caste marriage rules are known as asupundung and alangkahi karang hulu, which have a grave sanctions. After the independence, the sanctions were withdrawn through the enactment of the Decree of House of Representative of Bali Province Number 11 of 1951. However, the sanctions against inter-caste marriage are still applicable in society until now. The Decree of House of Representative of Bali Province Number 11 of 1951 is not following "the living law" as mentioned by Erlich which applicable in traditional society (Ali \& Mappalahere, 2003). Sanctions against inter-caste marriages are still applicable until now, such as moral sanction, psychological sanction, as well as social sanction namely the caste degradation for the woman which is known as patiwangi.

The enforcement of such sanctions is closely related to the adherence of people who have long been under the rule of the monarchy. Society's adherence to the law in that era is in accordance with John Austin's opinion, "a law is a command which obligies a person... law and other commands are said to proceed from superiors, and to bind or oblige inferior" (Darmodihardjo \& Shidarta, 2006). Obedience to sovereignty/ comand is perceived as "a moral duty" by the community, namely a moral obligation to obey a rule or a command. This moral obligation is then inherent in the culture of society, so it takes a long time to change it. This study was interested in analysing the impetus for change and development of rules on inter- caste marriage in balinese hindu community by analyzing the development of rules on inter-caste marriage in Balinese Hindu community and the sanctions for inter-caste marriages in the postindependence era. Traditional societies, everywhere, and their rules, are facing major challenges due to the rapid flow of information technology and technological developments. This makes slow adaptation less effective in dealing with challenges and threats to traditional values. Apart from that, forms of religious regulation also face threats from the modernization and secularization of values in society (Self \& Grabowski, 2009; Banerjee et al., 2013). This is a motivation for the author to research the institutionalization of inter-caste marriage in Balinese Hindu society. In modern legal systems, caste has long been considered to hinder equality before the law, and caste-based public rules have long been deemed unlawful in modern society. Several studies in various Hindu societies have confirmed a shift in the trend of change between castes, including in India (Ray et al., 2020; Narzary, \& Ladusingh, 2019; Kannan, 1961; Hortaçsu et al., 2019; Cahyaningtyas, 2016; Rukmini, 2014; Das et al., 2011). This makes caste-based marriage regulations relevant for carrying out religious obligations, but not for the modern law. In this context, this study investigates how the inter-caste marriage system is run as an effort to bridge traditional values and modern values based on legal equality and citizenship by taking Balinese society.

\section{RESEARCH METHOD}

This research is empirical legal research with a historical approach (Historical approach to legal research). The historical approach is carried out in the context of tracking legal history (Marzuki, 2005). The research examines the development of the rules on inter-caste marriage in the Balinese Hindu community from the past to the present. The research locations spread over four regencies in Bali. Several villages in four regencies were chosen by using the purposive method. The villages were chosen because there were various data. Primary data is from the respondents who experience inter-caste marriage and informants who know of inter-caste marriage cases. As for the historical approach used in this study, primary legal materials used in this research derive from Hindu Law which stipulated in Menawa Dharmacastra book, other Hindu books, peswara, the Decree of House of Representative of Bali Province Number 11 of 1951, Bhisama Sabha Pandita PHDI Pusat Number: 03/PHDI/X2002 concerning the Implementation of 
Catur wangsa, and The Results of the Supreme Assembly of the Pakraman Village Council Number III of 2010 .

The data analysis technique used in this research are interactive models. Activities are carried out starting from secondary data collection, primary data collection then continued with data processing, and then it is analysed by using theory, legal basis based on history, according to research focus. This technique is accompanied by argumentation, evaluation, and systematization, then draws a conclusion (based on deductive logic). The technical steps above were stated by Miles and A. Michael Huberman (1994).

\section{DEVELOPMENT OF THE RULES ON INTER-CASTE MARRIAGE IN BALINESE HINDU COMMUNITY}

The culture of community in the days of the Balinese monarchy era (13th century to the beginning of the colonial era) encouraged the imposition and adherence to the inter-caste marriage laws derived from inscriptions and Hindu religious books. The rules and sanctions contain magical religious values. Soerjono Soekanto (2005) argues that law is essentially a concretization of a system of values, specifically the legal values of a society. The value system is the core of the cultural value system of a society, especially the spiritual aspects of the cultural system.

In the colonial era, the legal culture of Hindu society encouraged changes in the substance and sanctions of inter-caste marriages, which were then stipulated in several peswara. For instance, the death sentence was changed to a sentence of exile, the sentence of exile was changed to a sentence of caste degradation. In line with the description, Abdul Manan (2018) argues that "the applicable law should pay attention to the legal culture of the community. The law will not apply effectively if it was forced to apply to the community. The influence of Hindu law causes the existence of non-physical sanctions, namely sanctions relating to religious ceremonies as a concretization of spiritual values.

In the days of independence, the political change caused the laws of the monarchy and colonial times to change because it was not following the principles of an independent State. However, that law had been in force for a long time until it becomes a culture of society. Consequently, the Decree of House of Representative of Bali Province Number 11 of 1951 cannot be implemented effectively. Therefore, intercaste marriages are still considered as customary violations. Although several attempts, such as enactments of regulations, have been made to reemphasised the abolition of sanctions for inter-caste marriages, sanctions are still imposed by the community. The theory of "law as a tool of social engineering" by Roscoe Pound which has been incorporated to the Decree of House of Representative of Bali Province Number 11 of 1951, Sabha Pandita of 2002, and Decree of MDP III of 2010 have not succeeded to change the social behavior completely. The sanctions of inter-caste marriage are closely related to the belief or religion, as substantiated in the theory of Reception in Comlexu by Salmon Keyzer, in which the Hindu community accepts the Hindu law as a whole.

Based on the observation, there are 22 inter-caste married couples after the enactment of Bhisama Sabha Pandita Number 03/Bhisama/ Sabha Pandita Parisadha Pusat/X/2002. The research was conducted in 4 regencies/ cities: Buleleng, Denpasar, Gianyar, and Tabanan. Of 22 married couples observed, 8 couples who refuse to disclose their identities did not do the caste degradation ceremony. They have to obey the applicable law. However, 14 couples are still conducting caste degradation ceremonies due to several reasons.

Some informants and respondents maintain the sanctions of caste degradation ceremony because of the following reasons:

IGNP (Age: 54 years old, Interview on Friday, 4 January 2019) from Buleleng has a daughter in law, namely Ida Ayu Ririn who has not pregnant yet. Then, the degradation ceremony of patiwangi was conducted at Bale Desa temple. Such ceremony was only conducted by Ida Ayu Ririn. Other respondents observed in Buleleng regency do not perform such a ceremony. Hence, this sanction is no longer applicable in Buleleng since the enactment of the Decree of House of Representative of Bali Province Number 11 of 1951.

Based on the observation in another regency, namely Gianyar, Novia Arini stated that his husband, I Gusti Jana Eka Putra, conducted such a ceremony in Babakan village, Gianyar. Such a ceremony was conducted so that the married will be everlasting and happy (NKKA, 32 years old, interview on Friday, 18 January 2019). Other respondents in Gianyar also 
conducted such a ceremony. Awig-awig of Desa Pakraman of Medahan, Gianyar does not regulate caste degradation. Nevertheless, these three respondents still maintain such a ceremony because it was considered a custom in the village.

In Denpasar city, a caste degradation ceremony was conducted by IGAS Age: 31 years old, interview on Saturday, 25 January 2019) at Bale Agung Temple in Sesetan village, Denpasar. Other respondents also conducted such a ceremony in Denpasar city. They conducted the ceremony at Bale Agung temple. Such ceremony was maintained due to the custom in Sesetan village. Awig-awig of Desa Adat Sesetan and Desa Adat Kesiman do not regulate such ceremonies, nevertheless, they still conducting such ceremonies as it is considered as a custom. According to MPD (76 years old, Interview on Saturday, 25 January 2019) caste degradation ceremony must be conducted because it is part of hereditary beliefs.

In Tabanan regency, DPSW (29 years old, interview on Saturday 26 January 2019.) conducted a caste degradation ceremony at Bale Agung temple in Kuwum village, Marga, Tabanan. Such ceremony is regulated under awig-awig of Desa Pakraman Kuwum in Pawos (Article) 39 concerning the Rules on Marriage. According to paragraph (5), a caste degradation ceremony should be conducted at Bale Agung temple if there is an inter-caste marriage. Other respondents in Tabanan conducted a caste degradation ceremony at their husband's house. Awig-awig in that village does not regulate such ceremony, however, based on their information, the priest told them to do such a ceremony before the marriage legalized according to Hindu Religion.

Awig-awig of Desa Pakraman Kuwum, Tabanan is the only awig-awig that regulates caste degradation. Other awig-awig do not regulate such rules but the community still maintains it. Sanctions in the form of caste degradation ceremony are currently carried out as a part of a tradition, no longer appearing as sanctions, such as at the beginning of independence.

Based on the description above, it takes considerable time to change conservative family law and community behaviour in Balinese society regarding mixed marriage (Ida Bagus, 2008; Bhajan, 2014; Ariani, 2010). Changes usually occur slowly, step by step. This tough change is also influenced by the caste system and the religious-magic nature that rests in the legal culture of society. Legal culture determines legal dynamics. Observing the issue above, Yehezjkel Dror's (2017) opinion acknowledges the existence of legal limits to change society when dealing with basic norms that are rooted in tradition and values. There will be fierce resistance if the changes are imposed coercively through the law. Based on the results of the study, several factors cause people to maintain castedegradation ceremonies: to get descendant, to make the marriage everlasting and happy, the ceremony is part of the custom of the village, the ceremony is regulated in the awig-awig of the Village, the priest order, or afraid of the curse.

\section{CONCLUSION}

The study aims to examine the historical origin of the rules and the rationale behind the caste degradation sanction imposed by the Balinese Hindu community which was being an impetus for intercaste marriage. The findings showed that the Development of the Rules on Inter-Caste Marriage in Balinese Hindu Community can be traced during the monarchy era, where inter-caste marriage was regulated in Hindu Law, Manawa Dharmacastra, Religion Books, Adigama Law Book, Brahma Tatwa Inscription, Widi Pepincatan Inscription, Puwadigama Inscription, and Dandang Bang Bungalan Inscription. During the colonial era, inter-caste marriage was regulated in Peswara 1876, Peswara 1900, and Peswara 1927c. After the independence, inter-caste marriage was regulated in The Decree of House of Representative of Bali Province Number 11 of 1951, Bhisama Sabha Pandita Parisadha Pusat Number 03/Bhisama/ Sabha Pandita Parisadha Pusat/X/2002, and the Decree of MDP Bali Number 01/Kep/Psm-3/MDP Bali/X/2010. These regulations have evolved from time to time and shown a change in a better direction, adjusting to the times and the authority in control. Balinese Hindu community still maintain sanctions for inter-caste marriages in the post-independence era due to several reasons, namely: to get descendant, to make the marriage everlasting and happy, the ceremony is part of the custom of the village, the ceremony is regulated in the awig-awig of the village, the priest order, or afraid of the curse.

The findings showed that it takes considerable time to change conservative family law and community behaviour in Balinese society regarding mixed marriage with the changes usually occuring slowly, step by step. This tough change is also influenced by the caste system and the religious-magic nature that rests in the legal culture of society. The findings 
demonstrated that legal culture determines legal dynamics and social behaviour regarding the acceptance of modern values. The findings theoretically contribute in its investigation about the inter-caste marriage system which is run as an effort to bridge traditional values and modern values based on legal equality and citizenship.

\section{REFERENCES}

Ali, Z., \& Mappalahere, F. (2003). Filsafat Hukum. Yayasan Masyarakat Indonesia Baru.

Ariani, I. G. A. A. (2010). Marriage Law and Divorce Based on Adat Law in Bali. Masalah-Masalah Hukum, 39(4), 297-301.

Atmaja, J. (2008). Bias gender: perkawinan terlarang pada masyarakat Bali. Kerjasama CV. Bali Media Adhikarsa \& Udayana University Press.

Banerjee, A., Duflo, E., Ghatak, M., \& Lafortune, J. (2013). Marry for what? Caste and mate selection in modern India. American Economic Journal: Microeconomics, 5(2), 33-72. https://doi.org/10.1257/mic.5.2.33

Bhajan, C. (2014). A Mixed Bag: The Inter-Religious Marriage Experience.

Cahyaningtyas, J. (2016). Inter-caste marriage in Bali: A gendered analysis of caste and its impact on Balinese women. Asian Journal of Women's Studies, 22(3), 193-207. https://doi.org/10.1080/12259276.2016.1205374

Darmodiharjo, D. (2006). Shidarta, Pokok-pokok filsafat hukum, apa dan bagaimana filsafat hukum Indonesia.

Das, K., Das, K. C., Roy, T. K., \& Tripathy, P. K. (2011). Dynamics of inter-religious and inter-caste marriages in India. Population Association of America, Washington DC, USA.

Dhar, R. L. (2013). Intercaste marriage: a study from the Indian context. Marriage \& family review, 49(1), 1-25. https://doi.org/10.1080/01494929.2012.714720

Djojodiguno, M. (1964). Asas-asas hukum adat. Jajasan Badan Penerbit Gadjah Mada.

Dror, Y. (2017). Public policy making reexamined. Routledge. https://doi.org/10.4324/9781315127774
Hortaçsu, A., Hwang, S. I. M., \& Mathur, D. (2019). Monetary incentives on inter-caste marriages in India: Theory and evidence. Journal of Development Economics, 141, 102371. https://doi.org/10.1016/j.jdeveco.2019.102371

Ida Bagus, M. (2008). Mixed marriages in Jembrana, Bali: Mediation and fragmentation of citizenship and identity in the postbomb (s) Bali world. The Asia Pacific Journal of Anthropology, 9(4), 346-362. https://doi.org/10.1080/14442210802493678

Kannan, C. T. (1961). Intercaste marriage in Bombay. Sociological Bulletin, 10(2), 53-68. https://doi.org/10.1177/0038022919610205

Kerepun, M. K. (2004). Benang kusut nama gelar di Bali. Bali Media Adhikarsa.

Mahmud, P. M. (2007). Legal research.

Manan, H. A. (2018). Aspek-aspek pengubah hukum. Prenada Media.

Marzuki, P. M. (2005). Penelitian hukum. Kencana.

Miles, M. B., \& Huberman, A. M. (1994). Qualitative data analysis: An expanded sourcebook. sage.

Narzary, P. K., \& Ladusingh, L. (2019). Discovering the Saga of Intercaste Marriage in India. Journal of Asian and African Studies, 54(4), 588-599. https://doi.org/10.1177/0021909619829896

Ray, T., Chaudhuri, A. R., \& Sahai, K. (2020). Whose education matters? An analysis of inter caste marriages in India. Journal of Economic Behavior \& Organization, 176, 619-633. https://doi.org/10.1016/j.jebo.2020.02.011

Rukmini, S. (2014). Just $5 \%$ of Indian marriages are inter-caste: survey. The Hindu, 13.

Saroja, K. (1999). Intercaste marriage and social dynamics in India: A critique. Indian Journal of Social Work, 60, 183-192.

Self, S., \& Grabowski, R. (2009). Modernization, inter-caste marriage, and dowry: An analytical perspective. Journal of Asian Economics, 20(1), 69-76. https://doi.org/10.1016/j.asieco.2008.07.001

Soekanto, S. (2005). Hukum Adat Indonesia.

Syahuri, T. (2013). Legislasi hukum perkawinan Indonesia: prokontra pembentukannya hingga putusan Mahkamah Konstitusi. Kencana.

Wiranata, I. G. A. (2005). Hukum Adat Indonesia Perkembangan dari Masa ke Masa. Citra Aditya Bakti.

DOI: https://doi.org/10.6000/1929-4409.2021.10.11

(C) 2021 Sadnyini and Gorda; Licensee Lifescience Global.

This is an open access article licensed under the terms of the Creative Commons Attribution Non-Commercial License (http://creativecommons.org/licenses/by-nc/3.0/) which permits unrestricted, non-commercial use, distribution and reproduction in any medium, provided the work is properly cited. 